\title{
DETERMINING IMPORTANT FACTORS ON FISH CONSUMPTION WITH CONJOINT ANALYSIS IN TEKIRDAG, TURKEY
}

\author{
Derya Ilkay Abdikoglu*, Gokhan Unakitan \\ Agricultural Economics, Faculty of Agriculture, Namık Kemal University, Tekirdag, Turkey, e-mail: deryailkay@nku.edu.tr
}

\begin{abstract}
In the world, there is an increasing consumption trend from red meat to white meat, especially to the fish. Despite the known benefits of fish consumption on human health, it is still not at the desired level in Turkey. The average fish consumption is $5.58 \mathrm{~kg}$ per capita in Turkey, and it is below the World $(14.9 \mathrm{~kg})$ and the EU $(16.89 \mathrm{~kg})$ average fish consumption. The aim of the study was to determine the importance level given to the factors that respondents consider when purchasing fish. In this study, surveys were conducted with 248 respondents. Conjoint analysis was used to determine the most important factors that influence respondents while purchasing fish. According to the results, fish consumption per capita in Tekirdag is $14.69 \mathrm{~kg}$ per year. In conjoint analysis results for all respondents, the most important factors in fish consumption are price (34.2\%), form (31.4\%), production method (26.9\%) and supply channel $(7.5 \%)$. The factors that influence respondents are changing according to the income groups. While price is the most important factor for respondents with a monthly income 1210 EUR or less, respondents with monthly income 1210 EUR and above pay attention to the processing type factor. Fish price and form are the most important factors for respondents. Retailers should aim to deliver fresh fish to consumers with a low-price policy. Due to this, it is needed to establish fish markets where necessary food controls and inspections are made, consumers relied, complying with European Union standards, fresh and cheap fish is sold.
\end{abstract}

Keywords: conjoint analysis, fish consumption, consumer behaviour, income levels

\section{Introduction}

In recent years, growing world population causes insufficiency of animal protein sources which have an important role in human nutrition. Fish is one of the important sources of animal protein. Fish consumption depends on several factors such as economic factors, the way of the product releasing to the market and consuming seafood habit. Fish which provides important benefits especially with the consumption during the development period of individuals, is consumed in different ways and in different amounts in different regions. The most important reason for this situation is cultural differences and different eating habits between different regions.

Turkey has rich fisheries resources. The average fish consumption per capita is $5.58 \mathrm{~kg}$ in Turkey and it is lower than the world and the EU average. The average fish consumption per capita is $14.9 \mathrm{~kg}$ per year in world and $16.89 \mathrm{~kg}$ per year in $\mathrm{EU}$ (FAO, 2018). It is a fact that increasing fish consumption, which is quite important in terms of health, will have a positive effect on future generations.

The aim of the study is to determine the importance level given to the factors that respondents consider when purchasing fish. In this study, the factors that respondents give importance when purchasing fish are determined by using conjoint analysis.

In previous studies using conjoint analysis about fish consumption preferences, price was determined as one of the most important attributes (Halbrent et al., 1992; Harrison et al., 1998; Boughanmi et al., 2007; Akpinar et al., 2009; Claret et al., 2012; Hanis et al., 2013; Geslani et al., 2015). Most of previous studies compared preference of wild-caught and farm-raised fish and wild-caught created higher utility than farm-raised (Akpınar et al., 2009; Claret et al., 2012; Musa et al., 2012; Geslani et al, 2015; Tomic et al., 2017). Halbrent et al. (1992), Harrison et al. (1998) and
Boughanmi et al. (2007) measured consumers' fish form preferences. Ariji (2010) determined that the information process is important for marketing and that labelling will be an effective marketing method. Izzhati et al. (2018) reported that the most important criteria in consumers' choice of packaged fish are brand, additional information, colour, material, shape and size.

\section{Materials and Methods}

In this study, data was collected from respondents living in Tekirdag province. Also, macro data are from Food and Agriculture Organization of the United Nations, local and international studies, projects and reports. Tekirdag is located in north western Turkey, in the Marmara Region. Tekirdag is also on the both Marmara Sea and Black Sea coast. Tekirdag is a developed province in terms of agriculture and industrial sectors. According to the sampling calculated from limited population formula (Miran, 2002) given below ( $\mathrm{N}=48000$ households, 90\% confidence interval, 5\% margin of error and $\mathrm{p}=\mathrm{q}=0.5$ to achieve maximum sample size), face to face surveys were applied to the randomly selected respondents representing 248 different households between January 2015 and May 2015. The number of households included in the sample were proportional to the number of households in the neighbourhoods (1):

$$
n=\frac{N p q}{(N-1) \sigma_{p}^{2}+p q}
$$

where: $\mathrm{n}$ - sample size,

$\mathrm{N}$ - population size,

$\mathrm{p}$ - expected proportion who consume fish,

$q-(1-p)$,

$\sigma_{p}^{2}$ - rate variance.

Conjoint analysis is one of the methods used to determine consumer preferences according to the different characteristics of any product. Conjoint 
analysis is based on the fact that the complexity of choices depends on more than one factor and each factor depends on two or more levels. The preference degrees given to products by respondents are the basis of the method. In the method, the utility level of each feature discussed are obtained by separating general evaluations for products with different properties offered to the respondent to the qualifications of these products (Green, Srinivsan, 1978).

The basic concept, which is measured as the personal choice judgment of individuals, is called utility. The aim of conjoint analysis within the framework of utility concept is estimation of relative contributions of independent variables to total utility and determination of variables that have the highest utility. Conjoint analysis is a statistical analysis conducted following the steps given below.

a. Determination of Factors and Factor Levels. Each variable used in the conjoint analysis includes various features of the product or service and their actual levels (Saraçlı, Şıklar, 2005).

b. Determination of Combinations. One of the variables is determined as a dependent variable and the effect of other variables on the selection of dependent variable levels is examined. The number of combinations is determined by crossing the levels of all factors involved in the study (full design). However, the very high number of combinations creates problems in terms of both applicability and predictability. For this reason, a subset of all theoretically possible combinations should be selected (orthogonal design). The selected combinations are asked to the respondents to score them.

c. Estimation of Utility Values. Conjoint analysis is used to decide partial utilities (partworths) $(\beta)$ for all factors based on scored data. In addition, the total utility (y) can be calculated for each combination with these partial utilities. Thus, the relative importance of the combinations is determined.
The additive model of the conjoint analysis (Prelec, 2002) is defined as (2):

$$
y_{k}=\sum_{j=1}^{j} \sum_{m=1}^{m_{j}} \beta_{j m} x_{j m}
$$

where: $y_{k}$ - estimated total utility for incentive $\mathrm{k}$

$\beta_{\mathrm{jm}}-$ partial utility for value (category) $\mathrm{m}$ of factor $\mathrm{j}$

$$
x_{j m}=\left\{\begin{array}{c}
1 ; \text { if incentive } k \text { has value } m \text { of factor } \\
0 ; \text { else }
\end{array}\right\}
$$

The partial utilities $(\beta)$ are estimated by the Ordinary Least Square (OLS) method. In the conjoint analysis, the most preferred combination can be determined by calculating the total utility value for each combination that the respondents scored.

In this study, Conjoint analysis was used in order to determine the importance of the factors of fish purchase and the importance level of these factors.

Table 1

Factors and factor levels used in conjoint analysis

\begin{tabular}{lll}
\hline \multicolumn{1}{c}{ Factors } & & Factor Levels \\
\hline Production Method & 1 & Farm-raised \\
& 2 & Wild-caught \\
\hline Price & 1 & $20 \%$ decrease \\
& 2 & Current price \\
& 3 & $20 \%$ increase \\
\hline Supply Channel & 1 & Restaurant \\
& 2 & Fishmonger \\
& 3 & Supermarket \\
\hline Form & 1 & Canned/Pickled \\
& 2 & Fresh \\
& 3 & Battered/Breaded \\
\hline
\end{tabular}

When the factor levels in Table 1 are examined, it is seen that there are $2 \times 3 \times 3 \times 3=54$ possible combinations. However, it is not possible for respondents to score 54 combinations in a healthy way.

Table 2

Combinations that respondents scored

\begin{tabular}{lllll}
\hline Combinations & Production method & Price & Supply channel & Form \\
\hline 1 & Farm-raised & $20 \%$ increase & Fishmonger & F \\
2 & Farm-raised & $20 \%$ decrease & Restaurant & C / P \\
3 & Wild-caught & Current price & Fishmonger & C/P \\
4 & Wild-caught & $20 \%$ decrease & Supermarket & $\mathrm{F}$ \\
5 & Wild-caught & $20 \%$ increase & Restaurant & $\mathrm{B} / \mathrm{B}$ \\
6 & Farm-raised & $20 \%$ decrease & Fishmonger & $\mathrm{B} / \mathrm{B}$ \\
7 & Farm-raised & Current price & Restaurant & $\mathrm{B} / \mathrm{B}$ \\
8 & Farm-raised & Current price & Supermarket & $\mathrm{C} / \mathrm{P}$ \\
9 & Farm-raised & $20 \%$ increase & Supermarket & \\
\hline
\end{tabular}

F-Fresh, C / P - Canned / Pickled, B / B - Battered / Breaded

9 combinations (the highest number obtained using two multipliers of $54(3 \times 3=9)$ as it is seen above) were chosen with orthogonal design from 54 combinations and respondents were asked to score these combinations from 1 to 10.9 combinations that respondents scored are shown in Table 2.

\section{Results and Discussion}

According to the results of the survey, the demographic structures of 248 respondents are shown in Table 3. A $44 \%$ of the respondents are female and $56 \%$ are male. Majority of respondents, around $59 \%$, are between 
26 and 40 years old. Majority of the respondents (around 42\%) have bachelor's degree. 64\% of the respondents are married and $36 \%$ are single. According to the average household income, $13 \%$ of the respondents are between 345-689 EUR, 34\% are between 690-1209 EUR, 27\% are between 1210-1724 EUR and $23 \%$ are 1725 EUR and above. According to the average household food expense, $23 \%$ of the respondents are between 85-174 EUR, 24\% are between 175-259 EUR, 27\% are between 260-344 EUR and $21 \%$ are 345 EUR and above.

Table 3

\section{Demographic structure of surveyed respondents}

\begin{tabular}{|c|c|c|}
\hline $\begin{array}{l}\text { Demographic } \\
\text { parameters }\end{array}$ & Groups & $\begin{array}{l}\text { Proportion, } \\
\%\end{array}$ \\
\hline \multirow[t]{2}{*}{ Gender } & Female & 43.7 \\
\hline & Male & 56.3 \\
\hline \multirow[t]{4}{*}{ Age } & $18-25$ & 10.3 \\
\hline & $26-40$ & 58.9 \\
\hline & $41-55$ & 26.7 \\
\hline & $55+$ & 4.1 \\
\hline \multirow[t]{2}{*}{ Marital status } & Married & 64.1 \\
\hline & Single & 35.9 \\
\hline \multirow[t]{6}{*}{ Education } & Primary & 5.6 \\
\hline & Secondary & 1.8 \\
\hline & High school & 21.1 \\
\hline & Associate degree & 8.5 \\
\hline & Undergraduate & 41.9 \\
\hline & Postgraduate & 21.1 \\
\hline \multirow{5}{*}{$\begin{array}{l}\text { Average monthly } \\
\text { household income } \\
\text { (EUR) }\end{array}$} & $<344$ & 2.9 \\
\hline & $345-689$ & 13.0 \\
\hline & $690-1209$ & 34.1 \\
\hline & $1210-1724$ & 27.0 \\
\hline & $1725<$ & 23.0 \\
\hline \multirow{5}{*}{$\begin{array}{l}\text { Average monthly } \\
\text { household food } \\
\text { expense (EUR) }\end{array}$} & $<85$ & 4.4 \\
\hline & $85-174$ & 23.0 \\
\hline & $175-259$ & 24.4 \\
\hline & $260-344$ & 26.7 \\
\hline & $345<$ & 21.5 \\
\hline
\end{tabular}

According to the survey results, fish consumption per capita in Tekirdag is $14.69 \mathrm{~kg}$ per year. Conjoint analysis was applied to all respondents without any grouping and respondents' preference criteria are determined. In order to examine whether the income levels of the respondents affect fish purchase preferences, the respondents were divided according to the income groups and the conjoint analysis was repeated.

\section{Conjoint analysis results for all respondents}

The utility coefficients and relative importance values obtained for each level of all factors are shown in Table 4. According to the results, the most important factor for respondents when purchasing fish is price with $34.22 \%$. 20\% reduction in prices has 1.061 utility coefficient and it provides the most utility. $20 \%$ reduction in prices is followed by current prices with 0.225 utility coefficient and $20 \%$ mark-up in prices with -1.287 utility coefficient. Also, Halbrent et al. (1992),
Harrison et al. (1998), Boughanmi et al. (2007), Akpınar et al. (2009), Claret et al. (2012), Hanis et al. (2013) and Geslani et al. (2015) determined that price is the most important factor in fish consumption.

The second factor is form with $31.36 \%$. The most preferred forms are fresh, canned/pickled and battered / breaded fish with $1.385,-0.619$ and -0.767 utility coefficients respectively. Production method is the third factor with $26.96 \%$. Wild-caught fish is preferred with 0.925 utility coefficients when compared farm-raised fish with -0.925 utility coefficient. According to previous studies, most of the consumers prefer wild-caught fish instead of farmraised fish (Akpinar et al., 2009; Claret et al., 2012; Musa et al., 2012; Geslani et al, 2015; Tomic et al., 2017).

Table 4

Conjoint analysis results

\begin{tabular}{llll}
\hline Factor & \multicolumn{1}{c}{$\begin{array}{c}\text { Factor } \\
\text { level }\end{array}$} & Utility & $\begin{array}{c}\text { Relative } \\
\text { importance }\end{array}$ \\
\hline Constant & & 3.994 & \\
\hline Prod. & Farm-raised & -0.925 & 26.96 \\
Method & Wild-caught & 0.925 & 34.22 \\
\hline Price & Current price & 0.225 & \\
& 20\% increase & -1.287 & \\
& 20\% decrease & 1.061 & 7.46 \\
\hline Supply & Restaurant & -0.269 & \\
Channel & Supermarket & 0.243 & \\
& Fishmonger & 0.026 & \\
\hline Form & Fresh & 1.385 & \\
& Canned/Pickled & -0.619 & \\
& Battered/Breaded & -0.767 & \\
\hline
\end{tabular}

The fourth factor is the supply channel with $7.46 \%$. The first one is the supermarket with 0.243 utility coefficient, the second one is the fishmonger with 0.026 utility coefficient of 0.026 and the third one is restaurant with -0.269 utility coefficient.

When approached in terms of marketing, retailers should aim to deliver fresh fish to consumers with a lowprice policy. For this purpose, products must be delivered from production department to the market in the fastest way and the cold chain should not be broken. In order to reduce fish price, it should be aimed to eliminate the intermediaries in the process that passes from the fish production centres or from the ports to the consumers. For this purpose, producers and fishmongers should be able to sell their own products by founding marketing cooperatives.

The utility scores of each combination were calculated by using the utility coefficients given in Table 5 . According to the calculated utility scores, the most preferred combination is number 4 with a score of 7.609. In other words, respondents prefer fresh, wild-caught fish sold at the supermarket with $20 \%$ reduction price. The second preferred combination is number 3 with 4.552 score. Respondents' second choice is canned / pickled fish done by using wild-caught fish. They prefer purchasing this product from the fishmonger and with current prices. 
Combination scores used in conjoint analysis

\begin{tabular}{clllll}
\hline Combination & $\begin{array}{c}\text { Production } \\
\text { method }\end{array}$ & \multicolumn{1}{c}{ Price } & Supply channel & \multicolumn{1}{c}{ Form } & Utility score \\
\hline 1 & Farm-raised & $20 \%$ increase & Fishmonger & Fresh & 3.194 \\
2 & Farm-raised & $20 \%$ decrease & Restaurant & Canned / Pickled & 3.243 \\
3 & Wild-caught & Current price & Fishmonger & Canned / Pickled & 4.552 \\
4 & Wild-caught & $20 \%$ decrease & Supermarket & Fresh & 7.609 \\
5 & Wild-caught & $20 \%$ increase & Restaurant & Battered / Breaded & 2.597 \\
6 & Farm-raised & $20 \%$ decrease & Fishmonger & Battered / Breaded & 3.390 \\
7 & Farm-raised & Current price & Restaurant & Fresh & 4.411 \\
8 & Farm-raised & Current price & Supermarket & Battered / Breaded & 2.771 \\
9 & Farm-raised & $20 \%$ increase & Supermarket & Canned / Pickled & 1.407 \\
\hline
\end{tabular}

Table 7

Respondent preferences according to income groups

\begin{tabular}{|c|c|c|c|c|c|c|}
\hline \multirow{2}{*}{\multicolumn{2}{|c|}{ Factors and factor levels }} & \multicolumn{5}{|c|}{ Income groups* } \\
\hline & & 1 & 2 & 3 & 4 & 5 \\
\hline \multirow[t]{2}{*}{ Production method } & Farm-raised & -0.702 & -0.871 & -1.019 & -1.083 & -0.671 \\
\hline & Wild-caught & 0.702 & 0.871 & 1.019 & 1.083 & 0.671 \\
\hline \multirow[t]{3}{*}{ Price } & Current price & 0.032 & 0.414 & 0.029 & 0.373 & 0.285 \\
\hline & $20 \%$ increase & -1.968 & -1.701 & -1.323 & -1.120 & -1.140 \\
\hline & $20 \%$ decrease & 1.937 & 1.287 & 1.294 & 0.747 & 0.854 \\
\hline \multirow[t]{3}{*}{ Supply channel } & Restaurant & -0.302 & -0.207 & -0.354 & -.104 & -0.364 \\
\hline & Supermarket & 0.127 & 0.310 & 0.264 & 0.085 & 0.366 \\
\hline & Fishmonger & 0.175 & -0.103 & 0.090 & 0.019 & -0.002 \\
\hline \multirow[t]{3}{*}{ Form } & Fresh & -0.016 & 1.494 & 1.131 & 1.644 & 1.630 \\
\hline & Canned / Pickled & 0.127 & -0.667 & -0.486 & -0.607 & -0.916 \\
\hline & Battered / Breaded & -0.111 & -0.828 & -0.645 & -1.038 & -0.715 \\
\hline
\end{tabular}

The least preferred combination was the 9th combination with the score 1.407 . The least preferred by respondents was canned/pickled products done with farm-raised fish, sold at the supermarket with $20 \%$ increased price. When the combinations with calculated utility score are examined in Table 5 , it is seen that respondents would buy canned / pickled products from fishmonger if the price is same. Respondents may also prefer to consume farm-raised fish in the restaurant with the condition that the price is same.

\section{Conjoint Analysis Results by Income Groups}

Distribution of surveyed respondents by monthly income groups per household is given in Table 6.

Table 6

Distribution of respondents by income groups (EUR)

\begin{tabular}{lccc}
\hline Income groups & Group code & Number & Ratio(\%) \\
\hline$<344$ & 1 & 8 & 3.2 \\
$344-689$ & 2 & 29 & 11.7 \\
$690-1209$ & 3 & 88 & 35.5 \\
$1210-1724$ & 4 & 65 & 26.2 \\
$1725<$ & 5 & 58 & 23.4 \\
\hline Total & & $\mathbf{2 4 8}$ & $\mathbf{1 0 0 . 0 0}$ \\
\hline
\end{tabular}

$35.48 \%$ of the respondents are in the 3rd income group. Other income groups are the 4th group with $26.21 \%$, the 5th group with $23.39 \%$, the 2nd group with $11.69 \%$ and the 1 st group with $3.23 \%$ respectively. When production method is examined, the utility coefficients of all groups are positive for wild-caught fish. In other words, wildcaught fish is priority for all groups. The 4th income group is the most reacting group for production method (Table 7). While $20 \%$ increase in prices has negative utility coefficient for each group, in case of a $20 \%$ decrease or no change in the prices, the utility coefficients are positive in each group. While the 1st income group is giving the most importance to the $20 \%$ decrease in prices, the 4th income group gives the least importance. The 1st income group gives the most reaction in case of a $20 \%$ increase in prices. It is observed that there is no significant difference between the reactions to the prices in 4th and 5th income groups. All income groups react to purchase fish from the restaurant. The 5th income group is the most reacting group to purchase fish from the restaurant. The income group that most prefer the supermarket to purchase fish is the 5th income group and the income group that most prefer the fishmonger is the 1 st income group. The reasons for this are thought that fish from fishmonger is more affordable, and high perception of prices due to the variety of fish sold in the supermarket. It is seen that supermarkets have high priority in fish purchasing place. It was determined that all groups have negative utility coefficient for battered / breaded fish. The most reactive income group for battered / breaded fish is the 4th income group. Although there is not much difference between the 4th and 5th group in fresh fish, the 
respondents in the 4th group preferred fresh fish. While canned / pickled fish is most preferred by the 1st income group, it is least preferred by the 5 th income group. The importance levels of factors according to income groups are shown in Table 8.

Table 8

\section{Relative importance of factors according} to income groups

\begin{tabular}{lrrrrc}
\hline \multirow{2}{*}{ Factors } & \multicolumn{6}{c}{ Income levels } \\
\cline { 2 - 6 } & \multicolumn{1}{c}{1} & \multicolumn{1}{c}{3} & \multicolumn{1}{c}{4} & \multicolumn{1}{c}{5} \\
\hline Production & 23.31 & 23.02 & 28.91 & 31.37 & 20.29 \\
method & $\mathbf{6 4 . 8 2}$ & $\mathbf{3 9 . 4 8}$ & $\mathbf{3 7 . 1 3}$ & 27.04 & 30.16 \\
Price & 7.92 & 6.83 & 8.77 & 2.74 & 11.04 \\
$\begin{array}{l}\text { Supply } \\
\text { channel }\end{array}$ & 3.95 & 30.68 & 25.19 & $\mathbf{3 8 . 8 5}$ & $\mathbf{3 8 . 5 1}$ \\
Form & & & & &
\end{tabular}

Accordingly, the 1st, the 2nd and the 3rd income groups give priority to price, while the 4 th and the 5 th income groups give priority to form. Although the form of the fish is the second most important factor for respondents, the demand for processed fish products is quite low. The main reason for this, fresh fish consumption is at the forefront in the Turkish culture. However, living conditions are changing in Turkey as all over the world. It is needed in order to save time and string out the fish consumption to 12 months, fish should be offered to consumers in different forms. While there is a wide range of canned fish in Europe, canned fish products are quite limited in Turkey. Therefore, the products can be diversified and extended to increase the canned fish consumption and thus total fish consumption.

\section{Conclusions}

According to the results the two most important factors that respondents consider in purchasing preferences are the price of fish (34\%) and the form of fish (31\%). Accordingly, it is seen that the price is an important competitive element and respondents prefer to buy fresh fish.

When the factors that respondents give importance to according to income level are examined, low-income group focuses directly on the price regardless whether the fish is canned / pickled, fresh or battered / breaded. The high-income group is more selective and prefers to consume fresh fish.

While fishmonger is preferred as a purchase place by the low-income group, supermarkets are preferred by rest of the income groups

Based on the most important reasons for respondents, fish markets where necessary food controls and inspections are made, consumers relied, complying with European Union standards, fresh and cheap fish is sold, need to be established. Furthermore, these fish markets should be easily accessible and centrally located.

\section{References}

1. Akpınar M.G., Dağıstan E., Mazlum Y., Gül M., Koç B., Yilmaz Y. (2009) Determining household preferences for fish consumption with conjoint analysis in Turkey. Journal of Animal and Veterinary Advances, Vol. 8(11), p. 2215-2222.

2. Ariji M. (2010) Conjoint analysis of consumer preference for bluefin tuna. The Japanese Society of Fisheries Science, Vol.76, p. 1023-1028.

3. Boughanmi H., Al-Musalami J., Al-Oufi H., Zaibet L. (2007) Estimating consumer preferences for value-added fish products in Oman. Journal of Food Products Marketing, Vol. 13(2), p. 47-68.

4. Claret A., Guerrero L., Aguirre E., Rincon L., Hernandez M.D., Martinez I., Benito Peleteiro J., Grau A., Rodriguez-Rodriguez C. (2012) Consumer preferences for sea fish using conjoint analysis: Exploratory study of the importance of country of origin, obtaining method, storage conditions and purchasing price. Food Quality and Preference, Vol. 26(2), p. 259-266.

5. FAO Food and Agriculture Organization of the United Nations, Fishery Statistical Databases. [accessed on 21.12.2018.]. Available: at: http://www.fao.org/ faostat/en/?\#data/CL

6. Geslani C., Loke M.K., Barnes-Mauthe M., Leung P. (2015) Seafood purchasing preferences of Hawaii Chefs: Comparing actual purchase to stated preferences from conjoint choice experiment. Journal of International Food \& Agribusiness Marketing, Vol. 27(1), p. 50-63.

7. Green P.E., Srinivasan V. (1978). Conjoint analysis in consumer research: Issues and outlook. Journal of Consumer Research, Vol. 5(2), p. 103-123.

8. Halbrendt C., Bacon R.J., Pesek J. (1992) Weighted least squares analysis for conjoint studies: The case of hybrid striped bass. ProQuest Agricultural Science Collection, Vol. 8 (2), p. 187-198.

9. Hanis A., Jinap S., Mad Nasir S., Alias R. (2013) Eliciting Malaysian consumer preferences for marine fish attributes by using conjoint analysis. World Applied Sciences Journal, Vol. 28 (12), p. 2054-2060.

10. Harrison R.W., Özayan A., Meyers A.P. (1998). A conjoint analysis of new food products processed from underutilized small crawfish. Journal of Agricultural and Applied Economics, Vol. 30 (2), p. 257-265.

11. Izzhati D.N., Mastrisiswadi H., Jazuli T.T. (2018) Consumer preferences for the design of smoked fish packaging using conjoint Analysis. Jurnal Ilmiah Teknik Industri, Vol. 17 (2), p. 177-185.

12. Miran B. (2002) Temel İstatistik. Ege Üniversitesi, 314p, İzmir.

13. Musa S.M., Aura C.M., Kundu R. (2012). Wild-caught fish versus aquaculture fish products: a fish marketing concept for aquaculture quality improvement, A case study of Nyanza Region, Kenya. International Journal of Science and Research, Vol. 3(9), p. 1972-1978.

14. Prelec D. (2002) Strategic Marketing Measurement. Fall 2002. Massachusetts Institute of Technology: MIT OpenCourseWare, https://ocw.mit.edu.

15. Saraçlı S., Şıklar E. (2005) Bireysel emeklilik şirketlerinin tercihinde etkili olan faktörlerin konjoint analizi ile incelenmesi. Anadolu Üniversitesi Sosyal Bilimler Dergisi, Vol. 5 (2), p. 1-12.

16. Tomic M., Luceviz Z., Tomljanovic T., Matulic D. (2017) Wild-caught versus farmed fish - consumer perception. Croatian Journal of Fisheries, Vol. 75, p. 41-50. 